\title{
EVALUATION OF ANTIUROLITHIC HERBAL FORMULA FOR UROLITHIASIS: A RANDOMIZED OPEN-LABEL CLINICAL STUDY
}

\author{
ULFATUN NISA*, PERISTIWAN R WIDHI ASTANA
}

Division of Clinical Study, Medicinal Plant and Traditional Medicine Research and Development Centre, National Institute Health and Research Development, Indonesia. Email: redfa01@gmail.com

Received: 10 November 2018, Revised and Accepted: 14 February 2019

\section{ABSTRACT}

Objective: The objective of the study was to evaluate the safety and efficacy of antiurolithic herbal formula (AHF) compared with commercial polyherbal lithotriptic (CPL) agent in urolithiasis subjects.

Materials and Method: The study was conducted with the design of purposive randomized open-label, end-blinded observation. The sample size and randomization were done by computer with generated statistical program. The total of subjects who met the inclusion and exclusion criteria was 200 patients. Every subject was given AHF or CPL according to their group and the intervention was carried out for 8 weeks. The study used the difference of stone's size and number as parameter to observe the efficacy between two groups. While in terms of safety, this study used biochemical parameters of liver and kidney function.

Results: A total of 191 adult patients with urolithiasis were enrolled. There were 97 and 94 subjects in AHF and CPL group, respectively. The study showed a significant size reduction of single's and multiple's stone in AHF group ( $\mathrm{p}<0.05)$. The size reduction difference in AHF group is greater than in CPL group. The number of multiple stone's subjects who treated AHF was significantly decreased. Whereas in CPL group, there was no significant size difference between pre and Post treatment. The biochemical parameters showed normal liver and renal function in both groups.

Conclusion: This study result indicates that AHF is safe and effective in the treatment of urolithiasis.

Keywords: Antiurolithic, Herbal, Formula, Clinical study.

(C) 2019 The Authors. Published by Innovare Academic Sciences Pvt Ltd. This is an open access article under the CC BY license (http://creativecommons. org/licenses/by/4. 0/) DOI: http://dx.doi.org/10.22159/ajpcr.2019.v12i4.30232

\section{INTRODUCTION}

Urolithiasis is the third most common urinary system disease in medical service [1-3]. Incidence of urolithiasis can be occurred in $10-12 \%$ of the population in developed countries with the highest age at 20-40 years [4]. It is more frequent in men than woman [5] which has High recurrence rate about 50\% (5-10 years) and 75\% (20 years) [6]. The underlying mechanism of urolithiasis can be explained as an imbalance between promoting and inhibitory component of stone formation in urine [3]. Based on Riskesdas, 2013, the prevalence of urolithiasis diagnosed by physician was $0.6 \%$ [7]. Urolithiasis can be found in the form of calcium, cystine, uric acid, or struvite stones. About $75 \%$ of urolithiasis consists of calcium salts which observed as calcium oxalate $(50 \%)$, calcium phosphate (5\%), and mixture of both (45\%) [1]. The first crystal in the loop of Henle or in the distal tubule was calcium phosphate. Excess of reactive oxygen species had important role in injury and inflammation of epithelial renal. Furthermore, it leads to the formation of stones when generated uncontrollably [8].

Extracorporeal shock wave lithotripsy is one of the standard procedures for eliminating nephrolithiasis. Although it is claimed safe, it still has negative effects such as traumatic effect of shock waves, decreasing renal function, the possibility of infection, or persistent stone fragments residue that consequences of increasing stone recurrence [9]. Therefore, there is an advanced idea to find another treatment to complete these methods using phytotherapy which can be considered as suitable longterm treatment for urolithiasis $[10,11]$. Hence, it is necessary to get antilithiatic drugs from herbal remedies with minimal side effect. Due to their efficacy and low toxicity, it could be the best alternative choice [12].

Several studies showed antilithiatic effect of medicinal plant such as Strobilanthes crispa L. Blume, Orthosiphon stamineus, Sonchus arvensis L., and Imperata cylindrica. Some of them have been proved about their therapeutic potential in vitro models [12,13]. The result of preliminary study of urolithiasis formula which is consist of S. crispa L. Blume, O. stamineus, S. arvensis L., and I. cylindrica, Curcuma longa, Curcuma xanthorrhiza, and Phyllanthus niruri revealed that size of stone can be reduced in the treatment and positive control compared to negative control group [13]. Furthermore, the aim of this study was to evaluate the safety and efficacy of antilithiatic formula in urolithiasis subjects.

\section{MATERIALS AND METHODS}

\section{Study design}

This study was conducted at medicinal plant and traditional medicine research and development center (B2P2TOOT), Ministry of Health, Indonesia. The study was carried out by 70 physicians and 20 pharmacists who had been trained about traditional medicinal services. The study design was purposive randomized open-label, end-blinded observation. The randomization sequence was computer generated. The investigators were blinded to treatment allocation. The total of subjects who met the inclusion and exclusion criteria was 200 patients [14]. Subjects were randomly divided into two groups which are antiurolithic herbal formula (AHF) group and commercial polyherbal lithotriptic (CPL) group. Laboratory and radiology examination used the accredited laboratories. Blass nier overzicht (BNO) and ultrasound result were reported by independent radiologist. This study had been approved by The Ethics Commission of National Institute of Health Research and Development, Health Ministry Republic of Indonesia (LB.02.01/5.2/KE 063/2016) on March 13, 2017.

\section{Preparation of materials}

In AHF group, each subject was given herbal formula which consisted of dried simplisia of $10 \mathrm{~g}$ S. arvensis, $6 \mathrm{~g}$ O. stamineus, $4 \mathrm{~g}$ 
Strobilanthes crispus, 5 g Imperata cylindrica, 5 g C. xanthorrhiza, $4 \mathrm{~g}$ Curcuma domestica, and $3 \mathrm{~g}$ P. niruri. Before being administered to the subject, the simplisia was managed and controlled by Post Harvest Division, B2P2TOOTTawangmangu Indonesia.

AHF was prepared boiling $1 \mathrm{~L}$ of water, then put simplisia in boiling water for $15 \mathrm{~min}$. Subjects were instructed to drink the filtered water twice a day after breakfast and dinner for 8 weeks.

The subjects in control group consumed CPL which consisted of the extract of $O$. stamineus $18 \mathrm{mg}$, S. crispa L. Blume $6 \mathrm{mg}$, S. arvensis L. $24 \mathrm{mg}$, and P. niruri $2.4 \mathrm{mg}$ and Plantago major $100 \mathrm{mg}$. Control's group received one capsule for 4 times daily.

\section{Inclusion and exclusion criteria}

Urolithiasis subjects with $<20 \mathrm{~mm}$ stone size, with or without clinical symptoms such as pain in the renal angle or flanks to the groin, urinary disturbance, and radiopaque stone through X-ray examination or ultrasound were included in the study. In the other hand, subject with a history of hypersensitivity of herbal formula, severe urinary tract infection, Grade III-IV hydronephrosis through ultrasonography (USG) or BNO, diabetes mellitus, creatinine $>2 \mathrm{gr} / \mathrm{dl}$, and pregnant women. Before the intervention, they were examined about clinical symptoms, size of urinary tract stone by USG, visual analog scale (VAS), liver and renal function (serum glutamic-oxaloacetic transaminase [SGOT], serum glutamic-pyruvic transaminase [SGPT], blood urea nitrogen [BUN], and creatinine), and kalium.

\section{Parameter of efficacy and safety}

Subjects were observed about their clinical symptoms using VAS assess pain degree. VAS was checked at baseline, $4^{\text {th }}$ week, and $8^{\text {th }}$ week of intervention. All subjects were evaluated their size of urolithiasis at baseline and the end of study ( $8^{\text {th }}$ week) by ultrasound.

The safety parameters were evaluated by examined SGOT, SGPT, BUN, and creatinine to asses liver and renal function at baseline, $4^{\text {th }}$ week, and $8^{\text {th }}$ week. In addition, other biochemical parameters (kalium) were also measured at baseline and the end of study ( $8^{\text {th }}$ weeks). The minimum of clinical outcome of this study was the reduction of stone size more than 50\% comparing with baseline. Furthermore, the stone was disappeared in 8 weeks.

All adverse events during treatment were recorded and evaluated. Side effect was obtained based on interview and observation of the subject and also through laboratory tests: Renal (BUN and creatinine) and liver function (SGOT and SGPT).

\section{Statistical analyses}

The data were analyzed statistically using a software program for statistical analysis version 18.0. Descriptive data were calculated and presented as table to assess demographic characteristic, size, and number of stone, VAS and biochemical parameters. Data analysis was used t-paired t-test to see the difference before and after treatment and independent $\mathrm{t}$-test to see the difference between two groups. The Wilcoxon test for paired test and Mann-Whitney U-test was used where there is an abnormal data distribution on Kolmogorov-Smirnov test result.

\section{RESULTS}

A total of 307 adult urolithiasis patients screened, we enrolled 200 subjects. As much 200 subjects were randomized to AHF and CPL group. Fig. 1 show that in AHF group, there were three dropped out subjects due to resigned and out of town. In CPL group, six subjects were dropped out of the study due to resign (4) and lost of follow-up (2). At baseline, Table 3 also shows there was no significant difference $(p>0.05)$ in demographic data, for example, age, sex, education, occupation, and body mass index (BMI) between AHF and CPL group. Baseline characteristics were similar in the two groups and shown in Table 1.

Table 2 shows that $85 \%$ and $83 \%$ of stone is found at pelvis renalis in AHF and CPL group, respectively. Subjects who had vesicolithiasis were $5.1 \%$ and $3.1 \%$ in formula and CPL group, respectively. The most type of stone was single stone in AHF group whereas also in CPL group. The total number of stone before treatment between two groups was similar and had no significant difference ( $p>0.05$ ). There was also no significant difference on the size of single and multiple of stone between two groups.

Table 1: The demographic characteristics of formula and CPL group

\begin{tabular}{|c|c|c|c|c|}
\hline Characteristics & AHF group n (\%) & CPL group n (\%) & Total $\mathbf{n}$ & $\mathbf{p}$ \\
\hline Age & & & & 0,412 \\
\hline $17-25 \mathrm{yr}$ & $3(3.09)$ & 0 & 3 & \\
\hline $26-35 \mathrm{yr}$ & $11(11.34)$ & 12 (12.77) & 23 & \\
\hline $36-45 \mathrm{yr}$ & $20(20.62)$ & $24(25.53)$ & 44 & \\
\hline $45-55 \mathrm{yr}$ & $46(47.42)$ & $44(46.81)$ & 90 & \\
\hline$>55 \mathrm{yr}$ & $17(17.53)$ & $14(14.89)$ & 31 & \\
\hline Sex & & & & 0.643 \\
\hline Men & $64(65.98)$ & 59 (62.77) & 123 & \\
\hline Woman & $33(34.02)$ & $35(37.23)$ & 68 & \\
\hline Education (finished) & & & & 0.312 \\
\hline Elementary of school & $17(17.53)$ & $26(27.66)$ & 43 & \\
\hline Junior high school & $13(13.40)$ & $9(9.27)$ & 22 & \\
\hline Senior high school & $31(31.96)$ & $31(32.98)$ & 62 & \\
\hline $\begin{array}{l}\text { University } \\
\end{array}$ & $36(37.11)$ & $28(29.79)$ & 64 & \\
\hline Occupation & & & & 0.355 \\
\hline Retired & $14(14.43)$ & $9(9.57)$ & 55 & \\
\hline Military/Police/Officer & 19 (19.59) & $27(28.72)$ & 46 & \\
\hline Private Employee & $13(13.40)$ & $19(20.21)$ & 32 & \\
\hline Entrepreneur & $21(21.65)$ & $14(14.89)$ & 35 & \\
\hline Labor/farmer/fisherman & 17 (17.53) & $13(13.83)$ & 30 & \\
\hline Others job & $13(13.40)$ & $12(12.77)$ & 25 & \\
\hline BMI & & & & 0.496 \\
\hline Underweight & $3(3.09)$ & $6(6.38)$ & 9 & \\
\hline Normal weight & $43(44.33)$ & $37(39.36)$ & 80 & \\
\hline Overweight & $42(43.30)$ & $42(44.68)$ & 84 & \\
\hline Obesity I & $8(8.25)$ & $8(8.51)$ & 16 & \\
\hline Obesity II & $1(1.03)$ & $1(1.06)$ & 2 & \\
\hline
\end{tabular}

AHF: Antiurolithic herbal formula, CPL: Commercial polyherbal lithotriptic, BMI: Body mass index 
The study showed significant size reduction both single and multiple type stone in AHF group $(\mathrm{p}<0.05)$ [Table 4]. Total of differences in AHF group greater than CPL group. On multiple type stone, the number of stone was also decreased significantly. However, the event was not found in CPL group (Table 5). There was a significant difference of single stone size between baseline and after 8 weeks intervention in both AHF and CPL group. Table 6 shows that the number of single and multiple stone was significantly decreased after AFH intervention compared to baseline. In contrast, there was no significant difference

Table 2: Urolithiasis characteristics

\begin{tabular}{lll}
\hline Characteristics of stone & AHF group n (\%) & CPL group n (\%) \\
\hline Location of stone & & \\
$\quad$ Pelvis renalis & $85(85.8)$ & $79(82.3)$ \\
Ureter & $9(9.1)$ & $14(14.6)$ \\
$\quad$ Vesica urinaria & $5(5.1)$ & $3(3.1)$ \\
$\begin{array}{l}\text { Type of stone } \\
\quad \text { Single }\end{array}$ & & \\
Multiple & $66(68)$ & $46(48.9)$ \\
\hline
\end{tabular}

AHF: Antiurolithic herbal formula, CPL: Commercial polyherbal lithotriptic

Table 3: Comparison between AHF and CPL groups in terms of size and number of stone before treatment (baseline)

\begin{tabular}{llllll}
\hline Size and number stone & AHF group & & \multicolumn{2}{l}{ CPL group } & \multirow{2}{*}{ P } \\
\cline { 2 - 2 } & Mean \pm SD & & Mean \pm SD & \\
\hline Size of single type stone & $10.82 \pm 8.19$ & & $8.07 \pm 5.19$ & 0.073 \\
Size of multiple type stone & $11.19 \pm 6.08$ & & $16.66 \pm 15.30$ & 0.283 \\
Number all of stones & $1.44 \pm 0.97$ & & $1.50 \pm 0.77$ & 0.656 \\
\hline
\end{tabular}

${ }^{*} \mathrm{p}<0.05$ significantly differences with confidence interval (CI) $95 \%$ of independent t-test, AHF: Antiurolithic herbal formula, CPL: Commercial polyherbal lithotriptic about the number of stone in CPL group. Thus, there was significant difference between the two groups at $8^{\text {th }}$ week.

The comparison result between two groups of intervention is shown in Fig. 2. In the AHF group, $43.29 \%$ of subjects who get herbal formula were included in the success category and $34.02 \%$ had little decreased than baseline. In CPL group, there were $35.10 \%$ and $27.66 \%$ categorized as successfully treatment and little decreased, respectively.

Both groups showed a significant decrease of VAS at the end of intervention (Table 7). The mean of VAS of AHF group subjects was $54.55 \pm 20.24$ at baseline and $29.01 \pm 17.57$ at $4^{\text {th }}$ week. It continued decreasing until $18.64 \pm 17.68$ at $8^{\text {th }}$ week. Using paired samples t-test, there was a significant decrease in the degree of pain compared to baseline.

The biochemical parameter was observed to evaluate the safety of AHF and CPL group. Table 8 shows no abnormalities value in SGOT and SGPT levels during intervention between two groups. Despite no statistically significant, there was decrease in SGOT levels in AHF group. While SGPT levels were decreased significantly at $4^{\text {th }}$ week compared to baseline. There were no statistically significant differences in renal and liver function with $p>0.05$. Creatinine and BUN are biochemical parameters to assess renal function. Subject who consumed formula had mean of creatinine $1.02 \pm 0.35 \mathrm{mg} / \mathrm{dl}$. It decreased in $1.00 \pm 0.30 \mathrm{mg} / \mathrm{dl}$ and 0.98 at 4 and 8 weeks, respectively. While in CPL group, creatinine levels tend to persist with $0.84 \pm 0.30 \mathrm{mg} / \mathrm{dl}, 0.85 \pm 0.29 \mathrm{mg} / \mathrm{dl}$, and $0.83 \pm 0.28 \mathrm{mg} / \mathrm{dl}$ at baseline, $4^{\text {th }}$ week, and $8^{\text {th }}$ week, respectively. Even though creatinine level was higher in AHF group than CPL, it was not statistically significant. There was no abnormalities potassium level in both two groups. It can be concluded that the potassium levels of all subjects before, during, and after the intervention of both groups were still in normal limits.

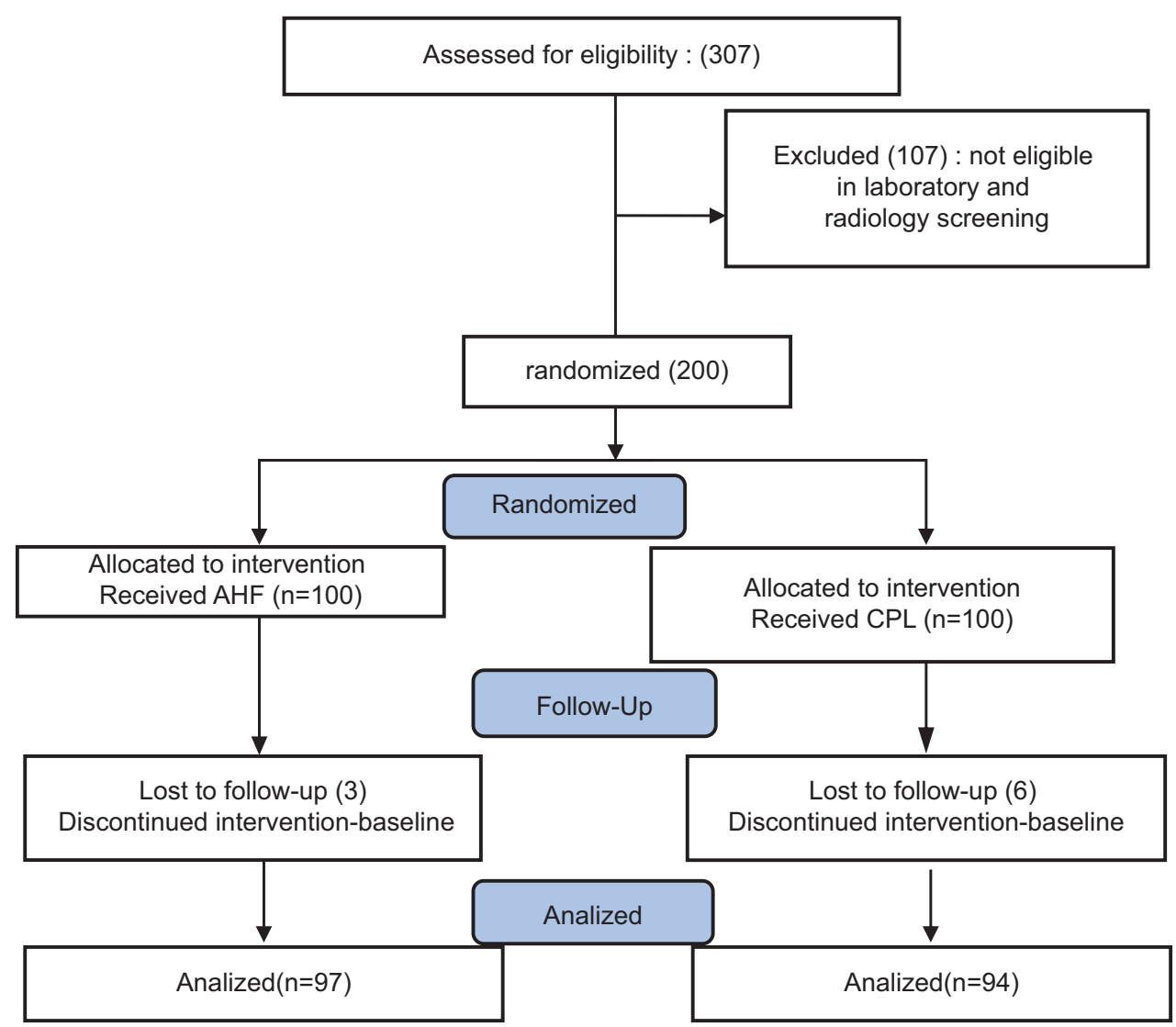

Fig. 1: Flowchart of recruitment and enrollment process 
Table 4: Size of single and multiple type stone in AHF and CPL group

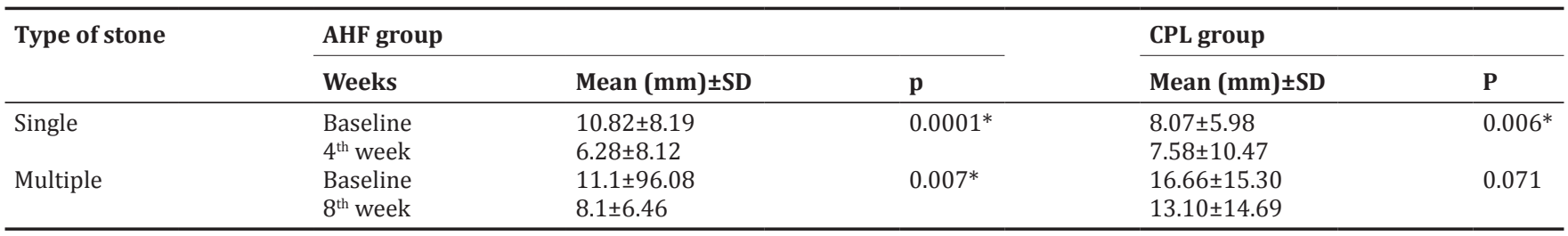

*p<0.05 swap independent t-test with "paired t-test", AHF: Antiurolithic herbal formula, CPL: Commercial polyherbal lithotriptic

Table 5: Comparison of size reduction of stone between AHF and CPL group

\begin{tabular}{lll}
\hline \multirow{2}{*}{ Type of stone } & AHF group & CPL group \\
\cline { 2 - 3 } & Size reduction $(\mathbf{m m}) \pm$ SD & Size reduction (mm) \pm SD \\
\hline Single's stone & $4.53 \pm 6.81$ & $0.49 \pm 9.57$ \\
Multiple's stone & $2.99 \pm 5.57$ & $3.56 \pm 11.14$ \\
\hline
\end{tabular}

${ }^{*} \mathrm{p}<0.05$ significantly differences with confidence interval (CI) 95\% of independent t-test, AHF: Antiurolithic herbal formula, CPL: Commercial polyherbal lithotriptic

Table 6: Number of stone analysis

\begin{tabular}{lllll}
\hline Type of stone & \multicolumn{2}{c}{ AHF group } & \multicolumn{2}{c}{ CPL group } \\
\cline { 2 - 3 } & Assesment time & Mean (pcs) \pm SD & Mean (pcs) \pm SD & p \\
\hline Single & Baseline & $1.00 \pm 0.00$ & $1.00 \pm 0.00$ & 0.656 \\
& $4^{\text {th }}$ week & $0.62 \pm 0.59^{\mathrm{a}}$ & $0.96 \pm 1.13$ & $0.036^{\mathrm{c}}$ \\
Multiple & Baseline & $2.48 \pm 1.27$ & $1.97 \pm 0.83$ & $1.58 \pm 1.14$ \\
& $8^{\text {th }}$ week & $1.72 \pm 1.19^{\mathrm{a}}$ & & \\
\hline
\end{tabular}

${ }^{\mathrm{a}}$ : $\mathrm{p}<0.05$ (CI 95\%) significant difference $8^{\text {th }}$ week compared to baseline in the same group, ${ }^{\mathrm{b}}: \mathrm{p}<0.05$ (CI $95 \%$ ) significant difference baseline compared two groups in all of the number of stone, ${ }^{c}: \mathrm{p}<0.05$ (CI 95\%) significant difference $8^{\text {th }}$ week compared two groups in all of the number of stone, CI: Confidence Interval, AHF: Antiurolithic herbal formula, CPL: Commercial polyherbal lithotriptic

Table 7: Comparison of VAS between AHF and CPL group

\begin{tabular}{lllllll}
\hline \multirow{2}{*}{ Day } & \multicolumn{2}{l}{ AHF group } & & \multicolumn{2}{l}{ CPL group } & \multirow{2}{*}{$\begin{array}{l}\text { p (AHF and } \\
\text { CPL group) }\end{array}$} \\
\cline { 2 - 3 } & Mean & SD & & Mean & SD & \\
\hline Baseline & 54.55 & 20.24 & & 48.19 & 30.08 & 0.333 \\
$4^{\text {th }}$ week & $29.01^{\text {a }}$ & 17.57 & & $28.33^{\text {c }}$ & 21.81 & 0.457 \\
$8^{\text {th }}$ week & $18.64^{\text {b }}$ & 17.68 & & $17.35^{\text {d }}$ & 18.98 & 0.200 \\
\hline
\end{tabular}

a: $\mathrm{p}<0.05$ (CI 95\%) significant differences $4^{\text {th }}$ week compared to baseline in same group, ${ }^{\text {b }}: \mathrm{p}<0.05$ (CI 95\%) significant differences $8^{\text {th }}$ week compared to baseline in same group, $\mathrm{c}: \mathrm{p}<0.05$ (CI 95\%) significant differences $4^{\text {th }}$ week compared to baseline between two groups, ${ }^{\mathrm{d}}: \mathrm{p}<0.05$ (CI 95\%) significant differences $8^{\text {th }}$ week compared to baseline between two groups, AHF: Antiurolithic herbal formula, CPL: Commercial polyherbal lithotriptic, VAS: Visual analog scale

\section{DISCUSSION}

Majority of the participants in this study were male. It is consistent with other previous studies. Men have greater muscle mass than woman that make their risk for urolithiasis is higher compare to woman. In addition, testosterone has ability to increase hepatic oxalate production in men. Estrogen can prevent the formation of oxalate stones because it keeps urine $\mathrm{pH}$ alkaline and increases citrate levels in urine $[12,15]$. Another study mentions that the risk ratio urolithiasis between male and female is 1.7:1 and 1.3:1 in 1997 and 2002, respectively [16], whereas the ratio of this study was 1.9:1 and 1.6:1 in AHF and CPL group, respectively. The ratio both of two groups has no statistical difference. The highest age of this study subjects was at the age of 45-55 years in two groups. Similar with another study that the peak incidence of urolithiasis at the age of 40-60 years old $[5,17]$.

A cohort study conducted in the USA showed that there is a close relationship between the incidences of urolithiasis with BMI [18]. In this study, the number of subjects with BMI more than normal was greater than normal weight $(>50 \%)$.

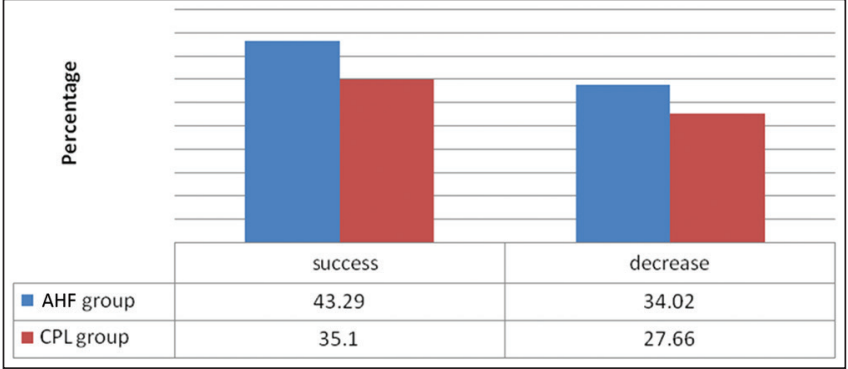

Fig. 2: Comparison between two groups of treatment

A study explained that urine $\mathrm{pH}$ was inversely proportional to body weight (bw) and vice versa. Hamano et al. said the excretion of promoting factors in the formation of oxalate stones cause strong correlation between obesity and the incidence of urolithiasis [19]

The highest of the prevalence of urolithiasis is located in pelvis renal. Other research explained the comparison between the upper and lower urinary tract stones was 9:1 [20].

As a result, the herbal formulation can significantly reduce the size and number of urolithiasis. In the CPL group, the size of single type stones decreased significantly but did not occur in multiple stone. While a significantly decrease happened on both of single and multiple stones in AHF group. Statistical test results of both two groups showed no significant differences in multiple stone reduction, whereas it was significant differences in single stone. Regarding the number of stones was also significantly decrease in single and multiple types in AHF whereas vice versa in CPL group. Thus, the comparison of the total difference between AHF and CPL was 1.9:1. In other words, formula has the capability to dissolve stones twice better than CPL. 
Table 8: Comparison of AHF and CPL groups in terms of biochemical parameters

\begin{tabular}{|c|c|c|c|c|c|c|}
\hline \multirow[t]{2}{*}{ Parameters } & \multicolumn{3}{|c|}{ AHF $($ Mean $\pm S D)$} & \multicolumn{3}{|c|}{ CPL $($ Mean $\pm S D)$} \\
\hline & Baseline & $4^{\text {th }}$ week & $8^{\text {th }}$ week & Baseline & $4^{\text {th }}$ week & $8^{\text {th }}$ week \\
\hline SGOT & $22.39 \pm 8.87$ & $20.67 \pm 6.09$ & $20.89 \pm 7.03$ & $22.75 \pm 9.05$ & $22.77 \pm 8.83$ & $22.43 \pm 8.45$ \\
\hline SGPT & $25.46 \pm 16.45$ & $21.59 \pm 10.02^{\mathrm{a}}$ & $21.73 \pm 10.15$ & $26.38 \pm 19.33$ & $26.71 \pm 21.30$ & $24.60 \pm 17.53$ \\
\hline BUN & $25.00 \pm 8.23$ & $25.66 \pm 8.03$ & $25.51 \pm 6.82$ & $24.71 \pm 8.90$ & $24.54 \pm 8.75$ & $24.68 \pm 9.27$ \\
\hline Creatinine & $1.02 \pm 0.35$ & $1.00 \pm 0.30$ & $0.98 \pm 0.28$ & $0.84 \pm 0.30$ & $0.85 \pm 0.29$ & $0.83 \pm 0.28$ \\
\hline Kalium & $4.14 \pm 0.51$ & & $4.13 \pm 0.64$ & $4.05 \pm 0.48$ & & $4.09 \pm 0.46$ \\
\hline
\end{tabular}

a: p<0.05 (CI 95\%) significantly differences day 28 compared to baseline in same group, AHF: Antiurolithic herbal formula, CPL: Commercial polyherbal lithotriptic, VAS:

Visual analog scale, BUN: Blood urea nitrogen, SGOT: Serum glutamic-oxaloacetic transaminase, SGPT: Serum glutamic-pyruvic transaminase

Seeing the results, it can be explained that the herbal formula for urolithiasis consists of $S$. arvensis L. leaves, $O$. stamineus Benth leaves, S. crispus B1 leaves, I. cylindrica roots, turmeric, temulawak, and meniran can reduce significantly size and number of stones. CPL group has a similar composition with herbal formula, but there are several components that are not present in the CPL but present in herbal formula. Moreover, the difference in solvent might be the other reasons for different capability. Several studies have suggested that water solvents are better than alcohol for plants which capable to dissolve urolithiasis. The potency of $S$. arvensis to dissolve kidney stones by water extracts is better than alcohol extracts [21].

The tempuyung leave (S. arvensis L.) contains soluble compounds in water such as mineral, carbohydrate, and glycoside (luteolin-7-0-glukosida and apigenin-7-O-glukosida) [22]. Other study revealed that $S$. arvensis L. Infuse $(0.50 \%)$ at dose of $8 \mathrm{ml} / \mathrm{kg}$ bw have diuretic effect $29.60 \%$ in male rabbit. Tempuyung is enriched with high kalium and natrium that useful to maintain electrolyte balance in kidney. Kalium can remove calcium in oxalate stone and make salt soluble compound in urine [23]. The majority of risk factor in pathogenesis urolithiasis is hyperoxaluria [24].

Diuretic activity of $O$. stamineus at dose of $50 \mathrm{mg} / \mathrm{kg}$ bw equivalent with HCT at dose of $10 \mathrm{mg} / \mathrm{kg}$ bw [25]. It has ability to prevent forming calcium crystal [26].

Kejibeling leaves (S. crispus B1) can solve nephrolithiasis and vesicolithiasis due to it has strong diuretic activity of kalium which can expulse calcium oxalate stone [27].

Potential action of herbal formulation might work in synergism process including diuretic, antimicrobial, antioxidant, antiinflammatory, antispasmodic, litholytic, and antilithogenic activities of its ingredients [28]. Several reviews explained that the mechanism of action beside diuretic for urolithiasis treatment is action to increase urolithiasis inhibitor by elevating urinary citrate excretion. In addition, antilithogenic effect with the effect of by decreasing urinary calcium and oxalate, thus reducing the risk of stone formation [29]. Antimicrobial and antioxidant are also one of antilithogenic effect to prevent stone formation [4]. Similarly, the previous study reported the relationship between free radicals and nephrolithiasis in which causes renal tubular cell damage, thus stimulates crystal formation [30]. Free radicals play an important role in stone formation by increasing protein-bound carbonyl groups [31]. Lipid peroxidation can cause urolithiasis by inducing oxidatively damaged protein which is released by damage cell $[32,30]$. These proteins can reduce inhibitor factors or increase the promoter of the crystallization process [30]. Medicinal plants which are enriched with antioxidants can prevent calcium oxalate precipitation in the kidneys and reduce oxalate excretion [33]. In this study, the presence of $C$. longa and C. xanthorrhiza besides has the ability as antioxidants as well as antimicrobial.

The safety of these herbal formulas is proved by normal biochemical parameters value. In addition, there is no significant difference between before and after the intervention in liver and renal function parameters. In AHF group, there was a significant decrease in SGPT which probably due to the hepatoprotector effect of $C$. xanthorrhiza and I. cylindrical $[34,35]$.

\section{CONCLUSION}

The results of this study indicated that AHF is safe and effective in the treatment of urolithiasis.

\section{ACKNOWLEDGMENT}

This study was a part of Saintifikasi Jamu formula (SJ) program that was carried out with the financial support of the Ministry of Health Republic of Indonesia. We would like to thank Head of Medicinal Plant and Traditional Medicine Research and Development Center, Tawangmangu, Indonesia, and all staff.

\section{AUTHORS' CONTRIBUTIONS}

Ulfatun Nisa designed the experimental study and carried out the analysis. Mr. P. R. Widhi Astana contributed in preparing the manuscript and revision. Both the authors have read and approved the final manuscript.

\section{CONFLICTS OF INTEREST}

The authors have none to declare.

\section{REFERENCES}

1. Sharma G, Lamichhane G. A review of plant based medicine in treatment of urolithiatic disorder. Pharm Innov J 2017;6:8-12.

2. Anbu J, Suman S, Swaroop KS, Kumar SL, Satheesh SK, Kannadhasan R. Antiurolithiatic activity of ethyl acetate root extract of Ichnocarpusfrutescens using ethylene glycol induced method in rats. J Pharm Sci Res. 2011;3:1182-9.

3. Poojar B, Ommurugan B, Adiga S, Thomas H. Evaluation of antiurolithiatic property of ethanolic extract of fennel seeds in male wistar albino rats. Asian J Pharm Clin Res 2017;10:313.

4. Gürocak S, Küpeli B. Consumption of historical and current phytotherapeutic agents for urolithiasis: A critical review. J Urol 2006; 176:450-5.

5. Peres A, Santos FM, Mandotti MR, Alberto L, Peres B. Metabolic investigation in patients with nephrolithiasis. Einstein 2017;15:452-6.

6. Aggarwal A, Singla SK, Gandhi M, Tandon C. Preventive and curative effects of Achyranthes aspera Linn. Extract in experimentally induced nephrolithiasis. Indian J Exp Biol 2012;50:201-8.

7. Badan Penelitian dan Pengembangan Kesehatan. Laporan Nasional Riset Kesehatan Dasar (RISKESDAS) 2013; 2013.

8. Jain K, Sood R. Short communication evaluation of renal epithelial cell protein under stress condition. Int J Pharm Pharm Sci 2016;8:37-40.

9. Tiwari A, Soni V, Londhe V, Bhandarkar A, Bandawane D, Nipate S. An overview on potent indigenous herbs for urinary tract infirmity. Asian J Pharm Clin Res 2012;5:3-8.

10. Jarald EE, Kushwah P, Edwin S, Asghar S, Patni SA. Effect of unex on ethylene glycol-induced urolithiasis in rats. Indian J Pharmacol 2011;43:466-8

11. Rodgers AL, Webber D, Ramsout R, Gohel MD. Herbal preparations affect the kinetic factors of calcium oxalate crystallization in synthetic urine: Implications for kidney stone therapy. Urolithiasis 2014;42:221-5.

12. Mikawlrawng K, Kumar S, Vandana. Current scenario of urolithiasis 
and the use of medicinal plants as antiurolithiatic agents in Manipur (North East India): A review. Int J Herb Med 2014;2:1-12.

13. Saryanto. Laporan Urolithiasis. Balai Besar Penelitian dan Pengembangan Obat dan Obat Tradisional;2012.

14. Association of the British Pharmaceutical Industry. Guidelines for Phase 1 Clinical Trials. 2012 th ed; 2012

15. Sodimbaku V, Pujari L. Urolithiasis-an updated review over genetics, pathophysiology and its clinical management. Int J Pharm Pharm Sci 2014;6:23-31.

16. Scales CD Jr., Curtis LH, Norris RD, Springhart WP, Sur RL, Schulman KA, et al. Changing gender prevalence of stone disease. J Urol 2007; 177:979-82.

17. Sakhaee K, Maalouf NM, Sinnott B. Clinical review. Kidney stones 2012: Pathogenesis, diagnosis, and management. J Clin Endocrinol Metab 2012;97:1847-60.

18. Sarica K, Altay B, Erturhan S. Effect of being overweight on stoneforming risk factors. Urology 2008;71:771-4.

19. Hamano S, Nakatsu H, Suzuki N, Tomioka S, Tanaka M, Murakami S, et al. Kidney stone disease and risk factors for coronary heart disease. Int J Urol 2005; 12:859-63.

20. Astana W, Zulkarnain Z. Studi Klinis Ramuan Jamu Batu Saluran Kemih. Kesan: Pros SEMNAS Si Manis Berujung Kronis; 2013.

21. Dalimartha S. Atlas Tumbuhan Obat Indonesia. Jakarta: Niaga Swadaya; 1999.

22. Chairul SM, Sumarny R. Aktivitas antioksidan ekstrak air daun tempuyung (Sonchus arvensis L) secara in-vitro antioxidant activity of aqueous extract of sonchus. Majalah Farm Indones 2003;14:208-15.

23. Ana $\mathrm{HH}$, Anggraini Y. Pengaruh frekuensi penggunaan teh daun tempuyung kering (Soncsus arvensis) terhadap daya larut. J Kesehat 2009;2:30-7

24. Nagal A, Singla RK. Herbal resources with antiurolithiatic effects: A review. Indo Glob J Pharm Sci 2013;3:6-14.
25. Adnyana K, Setiawan F, Insanu M. From ethnopharmacology to clinical study of Orthosiphon stamineus Benth. Int J Pharm Pharm Sci 2013;5:66-73.

26. Singh MK, Gidwani B, Gupta A, Dhongade H, Kaur CD, Kashyap PP, et al. A review of the medicinal plants of genus Orthosiphon (Lamiaceae). Int J Biol Chem 2015;9:318-31.

27. Dharma S, Aria M, Syukri EF. (Strobilanthes crispa (L) Blume) terhadap kelarutan kalsium dan oksalat sebagai komponen batu ginjal pada urin. Scientia 2014;4:34-7.

28. Kumaran MG, Patki PS. Evaluation of an ayurvedic formulation (Cystone), in urolithiasis: A double blind, placebo-controlled study. Eur J Integr Med 2011;3:23-8.

29. Butterweck V, Khan SR. Herbal medicines in the management of urolithiasis: Alternative or complementary? Planta Med 2009; 75:1095-103.

30. Srinivasan S, Kalaiselvi P, Sakthivel R, Pragasam V, Muthu V, Varalakshmi P, et al. Uric acid: An abettor or protector in calcium oxalate urolithiasis? Biochemical study in stone formers. Clin Chim Acta 2005;353:45-51.

31. Peng J, Jones GL, Watson K. Stress proteins as biomarkers of oxidative stress: Effects of antioxidant supplements. Free Radic Biol Med 2000;28:1598-606.

32. Green ML, Freel RW, Hatch M. Lipid peroxidation is not the underlying cause of renal injury in hyperoxaluric rats. Kidney Int 2005;68:2629-38.

33. Selvam R. Calcium oxalate stone disease: Role of lipid peroxidation and antioxidants. Urol Res 2002;30:35-47.

34. Ma J, Sun H, Liu H, Shi GN, Zang YD, Li CJ, et al. Hepatoprotective glycosides from the rhizomes of Imperata cylindrical. J Asian Nat Prod Res 2018;20(5):451-9.

35. Oon SF, Nallappan M, Tee TT, Shohaimi S, Kassim NK, Sa'ariwijaya MS, et al. Xanthorrhizol: A review of its pharmacological activities and anticancer properties. Cancer Cell Int 2015;15(1):100. 